\title{
Effects of Alloxan on Glucose-Stimulated Insulin Secretion, Glucose Metabolism, and Cyclic Adenosine 3', 5'-Monophosphate Levels in Rat Isolated Islets of Langerhans
}

\author{
W. S. Zawalich ${ }^{1}$, R. C. Karl' ${ }^{2}$, and F. M. Matschinsky ${ }^{3}$ \\ Departments of ${ }^{1}$ Physiology and ${ }^{3}$ Biochemistry and Biophysics, University of Pennsylvania School of Medicine, \\ Philadelphia, Pennsylvania, and ${ }^{2}$ Department of Surgery, University of Chicago School of Medicine, Chicago, Illinois, USA
}

\begin{abstract}
Summary. Insulin secretion was stimulated and cyclic adenosine 3', 5'-monophosphate (cAMP) levels were elevated in isolated rat islets by $27.5 \mathrm{mmol} / \mathrm{l}$ glucose. Alloxan caused a dose-dependent decrease in both variables with complete obliteration of insulin release at a concentration of $1.25 \mathrm{mmol} / \mathrm{l}$. D-glucose, in the presence or absence of extracellular calcium, or 3-0-methyl-D-glucose (both at $27.5 \mathrm{mmol} / \mathrm{l}$ ) protected completely against the effects of alloxan on both glucose-induced insulin release and cAMP levels. 3-0-Methylglucose did not stimulate insulin secretion or elevate cAMP and did not interfere with glucose-stimulated secretion or elevation of cAMP. When glucose-stimulated insulin release was abolished by alloxan, the metabolism of glucose, determined by the rate of ${ }^{3} \mathrm{H}_{2} \mathrm{O}$ formation from $\left[{ }^{-3} \mathrm{H}\right]$ glucose, was depressed by $20 \%$. It is concluded that alloxan altered the adenylate cyclase system such that it could no longer be stimulated by glucose. Glucose-stimulated insulin secretion or elevation of cAMP did not appear essential for glucose to protect against alloxan. Protection by 3-0methylglucose did not appear to be mediated through an alteration of cAMP metabolism. Alloxan did not inhibit glucose-induced insulin secretion by grossly altering glycolysis.
\end{abstract}

Key words: Alloxan, cyclic AMP, isolated islets, insulin secretion, glucose metabolism, 3-0-methylglucose, glyceraldehyde.

Alloxan has been widely used to induce permanent diabetes in laboratory animals $[1,2]$. It has also been shown to abolish acutely the ability of glucose to stimulate insulin secretion from pancreatic tissue
[3-6]. Most attention in the last few years has focused on the ability of various compounds, particularly glucose and 3-0-methylglucose, to prevent the effects of alloxan on islet tissue [7,8]. Research was spurred on by the observation that protection showed relative anomeric specificity for both $\alpha$-D-glucose and 3-0-methyl- $\alpha$-D-glucose. It was speculated that alloxan might prove to be a useful probe in determining the characteristics of the glucoreceptor system which is said to exist in islet tissue [9-11].

Since cyclic adenosine $3^{\prime}, 5^{\prime}$-monophosphate (cAMP) has been considered a possible second messenger in glucose-stimulated insulin secretion [12-16], the present experiments were undertaken to establish the possible involvement of cAMP in the altered insulin release patterns seen after alloxan. The role of glucose and 3-0-methylglucose, and their protective effects against alloxan poisoning were also studied.

\begin{abstract}
Methods
Animals

Male Holtzman rats (Madison, Wisc), weighing 300-400 g, had free access to food and water prior to collagenase isolation of the islets.
\end{abstract}

\section{Insulin Secretion}

The composition of the basic perifusion medium was: $\mathrm{NaCl}, 115$ $\mathrm{mmol} / \mathrm{l} ; \mathrm{KCl}, 5 \mathrm{mmol} / \mathrm{l} ; \mathrm{CaCl}_{2}, 2.2 \mathrm{mmol} / \mathrm{l} ; \mathrm{MgCl}_{2}, 1 \mathrm{mmol} / \mathrm{l}$; $\mathrm{NaHCO}_{3}, 24 \mathrm{mmol} / 1$; and $1.7 \mathrm{~g} / \mathrm{l}$ crystalline bovine serum albumin. The solution was continually gassed with $95 \% \mathrm{O}_{2}: 5 \% \mathrm{CO}_{2}$ and maintained at $37^{\circ}$ and $\mathrm{pH} 7.4$. The flow rate was $1 \mathrm{ml} / \mathrm{min}$. One hundred islets were used in each experiment. Each experiment was divided into 5 parts: 1) After loading the islets in the perifusion chambers, a $30 \mathrm{~min}$ equilibration period in the basic medium ensued. There were no additional substrates during this 


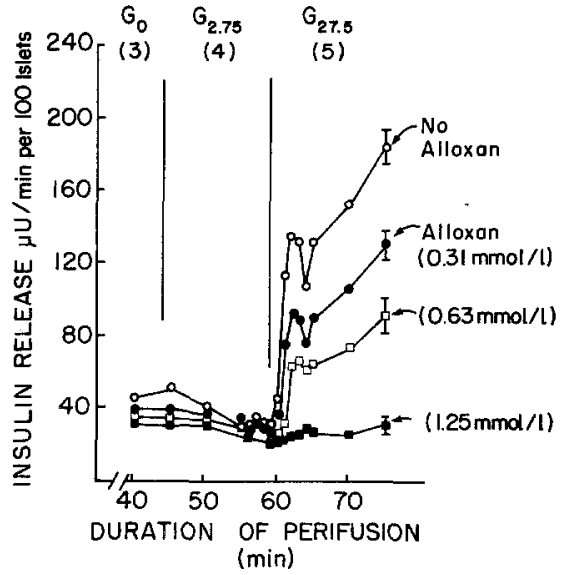

Fig. 1. Effects of various alloxan concentrations on glucoseinduced insulin secretion. Batches of 100 islets were perifused as explained in detail in Methods. During period 2 (not shown in the figure) the islets were exposed to $0(n=5), 0.31(n=3), 0.62$ $(\mathrm{n}=3), 1.25(\mathrm{n}=7) \mathrm{mmol} / \mathrm{l}$ alloxan. During period 5 the ability of the islets to respond to glucose $(27.5 \mathrm{mmol} / \mathrm{l})$ was examined. $\mathrm{G}_{0}$, no glucose; $G_{2.75}, 2.75 \mathrm{mmol} / 1$ glucose; $G_{27.5}, 27.5 \mathrm{mmol} / 1$ glucose. Mean \pm SEM of the last perifusate sample is shown. Other points represent mean values

time. 2) The equilibration period was followed by a $5 \mathrm{~min}$ exposure to either alloxan alone, alloxan and the sugar tested for protective effect, the sugar alone, or basic medium. 3) The basic medium for an additional $5 \mathrm{~min}$. 4) Glucose $(2.75 \mathrm{mmol} / \mathrm{l})$ for 15 min. 5) Glucose (2.75 $\mathrm{mmol} / \mathrm{l})$ with or without 3-0-methylglucose $(27.5 \mathrm{mmol} / \mathrm{l})$; glucose $(27.5 \mathrm{mmol} / \mathrm{l})$ with or without $3-0$ methylglucose $(27.5 \mathrm{mmol} / \mathrm{l})$ for $20 \mathrm{~min}$. Basal glucose was omitted from the perifusion medium during Periods 1 and 3 to avoid any possible interaction with alloxan. The omission of exogenous fuel for this period of time did not have a detrimental effect on islet responsiveness (unpublished observations). All sugars were dissolved at least $30 \mathrm{~min}$ before use to allow mutarotation to occur. After termination of the perifusion, the filter used to support the islets in the perifusion chamber, was removed, quickly frozen, and cAMP determined as previously reported [14]. It should be noted that the initial concentrations of alloxan are presented. However, because the half life of alloxan is only $1 \mathrm{~min}$ in this system [4] and the dead space in the perifusion system is approximately $2 \mathrm{ml}$ the effective alloxan concentration reaching the islets was considerably less than that given. (Since the flow rate was $1 \mathrm{ml} / \mathrm{min}$ it takes 2 min for the alloxan medium to reach the islets.) In experiments where calcium was omitted from the medium, this cation was absent during period $1(30 \mathrm{~min})$, period $2(5 \mathrm{~min})$, and period 3 (5 min). Calcium, $2.2 \mathrm{mmol} / \mathrm{l}$, was readded in period 4 . Insulin release was measured by radioimmunossay [17] using human insulin as standard.

\section{Metabolic Experiments}

In selected perifusion experiments in the presence or absence of alloxan the ability of islets to utilise glucose was determined by the rate of tritiated water formation from $\left[5{ }^{3} \mathrm{H}\right]$ glucose. In these experiments, the filter with attached islets was removed from the perifusion chamber after the $20 \mathrm{~min}$ stimulation (period 5) with glucose $(27.5 \mathrm{mmol} / \mathrm{l})$. The medium used to incubate the islets was identical to the perifusion medium except for the presence of $\left[5^{-3} \mathrm{H}\right]$ glucose, 4 to $5 \mu \mathrm{l}$, and was prepared in the following man- ner. Stock $\left[5-{ }^{3} \mathrm{H}\right]$ glucose was placed in a $10 \times 75 \mathrm{~mm}$ glass tube and desiccated overnight. To this was added $300 \mu \mathrm{l}$ of the warmed and oxygenated perifusion medium at the desired glucose concentration; $125 \mu \mathrm{l}$ of this medium was added to the vial which contained the islets and another $125 \mu \mathrm{l}$ to a vial without islets. This was necessary to control for the small ${ }^{3} \mathrm{H}_{2} \mathrm{O}$ blank in the $\left[5-{ }^{3} \mathrm{H}\right]$ glucose. The vials were subsequently placed in a metabolic shaker ( 100 strokes $/ \mathrm{min}$ ) at $37^{\circ}$ for 1 hour. At the end of this time $2 \times 50$ $\mu \mathrm{l}$ of incubation medium was transferred to a $6 \times 30 \mathrm{~mm}$ glass tube to which had been added $5 \mu \mathrm{l}$ of $1 \mathrm{~mol} / 1 \mathrm{HCl}$. The acid tended to minimise in some unknown fashion the tritiated water formed from the unused tritiated glucose. The small glass tubes were then placed in a scintillation vial to which had been added $0.5 \mathrm{ml}$ distilled water. The vials were stoppered and allowed to equilibrate at $37^{\circ}$ overnight in an air-circulated incubation room. ${ }^{3} \mathrm{H}_{2} \mathrm{O}$ standards were treated in the same manner to control for incomplete equilibration. At the end of the period the vials were removed from the incubation room and allowed to reach room temperature. The small inner tube was removed and placed in another scintillation vial. This tube contained the unused $\left[5-{ }^{3} \mathrm{H}\right]$ glucose. Scintillation fluid $(10 \mathrm{ml})$ was added to all vials and the radioactivity determined. After the appropriate corrections for incomplete ${ }^{3} \mathrm{H}_{2} \mathrm{O}$ equilibration, usage was calculated as previously reported [18-20].

\section{Statistics}

Significance of difference between experimental groups were tested by Student's t-test.

\section{Chemicals}

Alloxan monohydrate, D-glucose, and 3-0-methyl-D-glucose were all purchased from Sigma Chemical Co, St. Louis, Mo. Pure D-glyceraldehyde was obtained from Koch-Light Laboratories Ltd, Colnbrook, England. Collagenase (Type IV) was from Worthington Biochemical, Freehold, N. J. $\left[5-{ }^{3} \mathrm{H}\right]$ glucose was obtained from Amersham-Searle, Arlington, Il. and the ${ }^{3} \mathrm{H}_{2} \mathrm{O}$ from New England Nuclear, Boston, MA. Scintillation fluid (3a 70) was purchased from Research Products International, Elk Grove, Il. Bovine serum albumin was obtained from Armour Pharmaceuticals, Kankakee, Ill.

\section{Results}

\section{Insulin Release}

A 5 min exposure to various concentrations of alloxan during period 2 produced a dose-dependent decrease of glucose-stimulated insulin secretion (Fig. 1). Complete blockade was observed at 1.25 $\mathrm{mmol} / 1$. If $27.5 \mathrm{mmol} / \mathrm{l}$ glucose or 3-0-methylglucose were present during the $5 \mathrm{~min}$ exposure to 1.25 $\mathrm{mmol} / \mathrm{l}$ alloxan, complete protection of glucoseinduced secretion was observed (Fig. 2). In the absence of normal extracellular calcium $(2.2 \mathrm{mmol} / \mathrm{l})$, which prevents the elevation of insulin secretion [21], glucose still protected against the deleterious effects of alloxan (results not shown). D-Glyceraldehyde, $27.5 \mathrm{mmol} / \mathrm{l}$, provided only marginal protection against alloxan (Fig. 2). Taking into account basal 


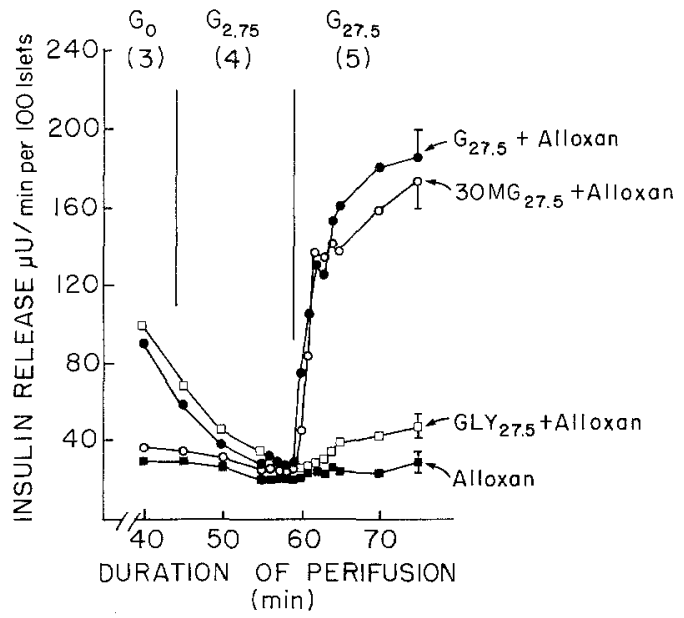

Fig. 2. Protection against alloxan poisoning of glucose-induced insulin secretion by various compounds. Islets were perifused as in Figure 1 except that in period 2 (not shown) the islets were exposed to alloxan $(1.25 \mathrm{mmol} / \mathrm{l})$ alone or with glucose $(\mathrm{G})$ $(n=5)$, 3-0-methylglucose (3OMG) $(n=4)$, or glyceraldehyde (GLY) $(\mathrm{n}=4)$, all at $27.5 \mathrm{mmol} / \mathrm{l}$. Subsequently, the ability of the islets to respond to $27.5 \mathrm{mmol} / \mathrm{l}$ glucose was examined. Other comments as for Figure 1

insulin secretion $(20 \mu \mathrm{U} / \mathrm{min}$ per 100 islets $)$, the response was $16 \%$ of that seen in non-poisoned islets (see Fig. 1). 3-0-methylglucose, $27.5 \mathrm{mmol} / 1$, neither elevated basal release nor interfered with the stimulant action of glucose (Fig. 3).

\section{cAMP in Islets}

In Table 1 the effects of various doses of glucose and alloxan on islet cAMP are shown. With $2.75 \mathrm{mmol} / 1$ glucose present during the $20 \mathrm{~min}$ stimulatory period (line 1) cAMP levels averaged $1.59 \pm 0.19$ (mean \pm SEM) pmol/100 islets. Pretreatment with 0.31 or $1.25 \mathrm{mmol} / 1$ alloxan during period 2 did not alter these basal levels (Table 1, lines 2 and 3). With 27.5 $\mathrm{mmol} / \mathrm{l}$ glucose present in the final period, cAMP increased 2.3-fold (line 4). Pretreatment with various alloxan doses resulted in a dose-dependent decrease of the cAMP response to $27.5 \mathrm{mmol} / 1$ glucose. After exposure to $1.25 \mathrm{mmol} / 1$ alloxan in period 2 , cAMP values in the presence of $27.5 \mathrm{mmol} / \mathrm{l}$ glucose were not different from those observed with $2.75 \mathrm{mmol} / 1$ glucose (compare lines 1 and 7). 3-0-methylglucose $(27.5 \mathrm{mmol} / \mathrm{l})$ neither interfered with the ability of $27.5 \mathrm{mmol} / 1$ glucose to elevate cAMP nor was 3-0methylglucose capable of elevating cAMP in the presence of basal glucose (lines 8 and 9).

In Table 2 the results of experiments which tested the ability of various compounds to protect against alloxan are shown. Glucose $(27.5 \mathrm{mmol} / \mathrm{l})$ or $3-0$ -

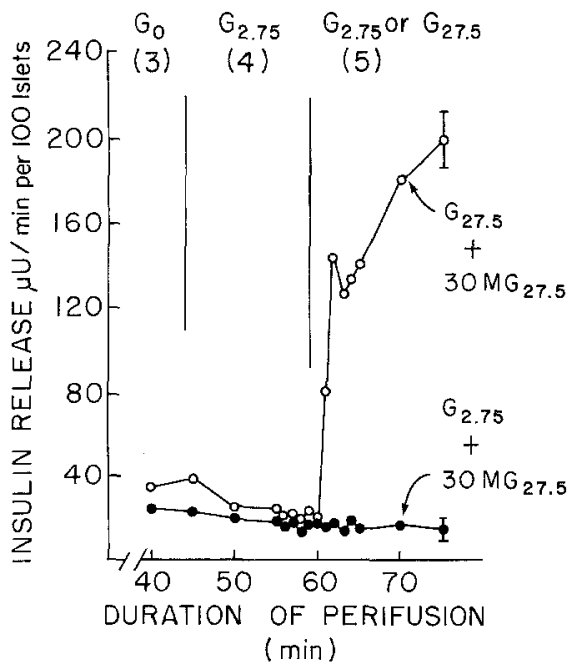

Fig. 3. Lack of effect of 3-0-methylglucose on insulin secretion. Islets were perifused as previously noted (See legend to Figure 1). During period 5 , the islets were exposed to $27.5 \mathrm{mmol} / \mathrm{l} 3-0$ methylglucose in the presence of 2.75 or $27.5 \mathrm{mmol} / 1$ glucose ( $n=4$ for each condition). Other comments as for Figure 1

Table 1. Effects of alloxan and sugars on cAMP in isolated islets

\begin{tabular}{|c|c|c|c|c|c|}
\hline \multirow[t]{2}{*}{ Line } & \multicolumn{2}{|l|}{ Period } & \multicolumn{2}{|l|}{ Period } & \multirow{2}{*}{$\frac{\text { cAMP levels }}{\text { (pmol/100 islets) }}$} \\
\hline & $\begin{array}{c}2 \\
\text { Addition }\end{array}$ & $\begin{array}{l}\text { Concn. } \\
\mathrm{mmol} / \mathrm{l}\end{array}$ & $\begin{array}{c}5 \\
\text { Addition }\end{array}$ & $\begin{array}{l}\text { Concn. } \\
\text { mmol/1 }\end{array}$ & \\
\hline 1 & Glucose & 0 & Glucose & 2.75 & $1.59 \pm 0.19^{\mathrm{a}}[4]$ \\
\hline 2 & Alloxan & 0.31 & Glucose & 2.75 & $1.53 \pm 0.15[3]$ \\
\hline 3 & Alloxan & 1.25 & Glucose & 2.75 & $1.48 \pm 0.20[4]$ \\
\hline 4 & Glucose & 0 & Glucose & 27.5 & $3.58 \pm 0.20[5]$ \\
\hline 5 & Alloxan & 0.31 & Glucose & 27.5 & $2.64 \pm 0.10[3]$ \\
\hline 6 & Alloxan & 0.63 & Glucose & 27.5 & $2.09 \pm 0.16[3]$ \\
\hline 7 & Alloxan & 1.25 & Glucose & 27.5 & $1.64 \pm 0.19[7]$ \\
\hline 8 & Glucose & 0 & $\begin{array}{l}\text { Glucose } \\
+ \\
3-0 \text {-methyl- } \\
\text { glucose }\end{array}$ & 27.5 & $3.68 \pm 0.21[4]$ \\
\hline 9 & Glucose & 0 & $\begin{array}{l}\text { Glucose } \\
+ \\
3-0 \text {-methyl- } \\
\text { glucose }\end{array}$ & 2.75 & $1.39 \pm 0.18[4]$ \\
\hline
\end{tabular}

Batches of 100 islets were perifused as follows. Period 1, 30 minutes with zero glucose; Period 2, 5 min with zero glucose and different alloxan doses; Period 3, 5 min with zero glucose; Period $4,15 \mathrm{~min}$ with glucose, $2.75 \mathrm{mmol} / 1$; Period 5, $20 \mathrm{~min}$ with glucose at $2.75 \mathrm{mmol} / \mathrm{l}$, glucose at $27.5 \mathrm{mmol} / \mathrm{l}$, glucose at $27.5 \mathrm{mmol} / 1$ and 3-0-methylglucose at $27.5 \mathrm{mmol} / \mathrm{l}$, or glucose at $2.75 \mathrm{mmol} / \mathrm{l}$ plus 3-0-methylglucose at $27.5 \mathrm{mmol} / \mathrm{l}$

${ }^{a}$ Mean \pm SEM for the numbers of experiments stated in parentheses 
Table 2. Effects of glucose, 3-0-methylglucose and glyceraldehyde against alloxan depression of cAMP levels

\begin{tabular}{|c|c|c|c|c|c|c|}
\hline \multirow[t]{2}{*}{ Line } & \multicolumn{2}{|l|}{ Period } & \multicolumn{2}{|l|}{ Period } & \multicolumn{2}{|l|}{ cAMP levels } \\
\hline & $\begin{array}{c}2 \\
\text { Addition }\end{array}$ & $\begin{array}{l}\text { Concn. } \\
\mathrm{mmol} / 1\end{array}$ & $\begin{array}{l}5 \\
\text { Addition }\end{array}$ & $\begin{array}{l}\text { Concn. } \\
\mathrm{mmol} / \mathrm{l}\end{array}$ & (pmol/100 islets) & $\mathrm{p}$ values \\
\hline 1 & Alloxan & 1.25 & Glucose & 27.5 & $1.64 \pm 0.19^{\mathrm{a}}[7]$ & \\
\hline 2 & Glucose & 27.5 & Glucose & 2.75 & $1.69 \pm 0.21[3]$ & 2 vs $1:$ N.S.* \\
\hline 3 & $\begin{array}{l}\text { Alloxan } \\
+ \\
\text { Glucose }\end{array}$ & $\begin{array}{r}1.25 \\
27.5\end{array}$ & Glucose & 27.5 & $3.31 \pm 0.30[5]$ & 3 vs $1: p<0.05$ \\
\hline 4 & $\begin{array}{l}\text { Alloxan } \\
+ \\
\text { 3-0-methylglucose }\end{array}$ & $\begin{array}{r}1.25 \\
27.5\end{array}$ & Glucose & 27.5 & $3.25 \pm 0.17[4]$ & 4 vs $1: p<0.05$ \\
\hline 5 & $\begin{array}{l}\text { Alloxan } \\
+ \\
\text { Glyceraldehyde }\end{array}$ & $\begin{array}{r}1.25 \\
27.5\end{array}$ & Glucose & 27.5 & $1.90 \pm 0.16[4]$ & 5 vs 1 :N.S. \\
\hline
\end{tabular}

All islets were perifused as explained in the legend of Table 1 . In Period 2, in addition to $1.25 \mathrm{mmol} / 1$ alloxan, $27.5 \mathrm{mmol} / 1 \mathrm{glucose}, 27.5$ $\mathrm{mmol} / 1$ 3-0-methylglucose, or $27.5 \mathrm{mmol} / 1$ glyceraldehyde was present

a Results are presented as means \pm SEM for the numbers of experiments stated in parentheses

* N.S. $=$ Not significant $(\mathrm{p}>0.05)$ using Student's t-test

methylglucose $(27.5 \mathrm{mmol} / \mathrm{l})$ protected the islet cAMP responsiveness to $27.5 \mathrm{mmol} / 1$ glucose (lines 3 and 4). In contrast $27.5 \mathrm{mmol} / 1 \mathrm{D}$-glyceraldehyde had a slight but insignificant protective effect (line 5).

Exposure of islet tissue to $27.5 \mathrm{mmol} / 1$ glucose, $27.5 \mathrm{mmol} / 13-0$-methylglucose, or $27.5 \mathrm{mmol} / 1 \mathrm{gly}-$ ceraldehyde alone during period 2 did not affect insulin release measured during exposure to 27.5 $\mathrm{mmol} / \mathrm{l}$ glucose in period 5. Levels of cAMP measured after the perifusion were also comparable and averaged $3.72 \pm 0.25(\mathrm{n}=3), 3.47 \pm 0.32(\mathrm{n}=3)$, and $3.89 \pm 0.30(n=3)$ under these conditions respectively.

In a further series of experiments, the ability of alloxan poisoned islets to produce ${ }^{3} \mathrm{H}_{2} \mathrm{O}$ from $\left[5-{ }^{3} \mathrm{H}\right]$ glucose was determined. Glucose usage in control, untreated islets averaged $104.9 \pm 6.5 \mathrm{pmol} / \mathrm{islet} /$ hour (mean $\pm S E M, n=4$ ) measured at a glucose concentration of $27.5 \mathrm{mmol} / 1$ while alloxan-treated islets utilised $83.7 \pm 5.0 \mathrm{pmol}$ of glucose/islet/hour at the same glucose concentration $(p<0.05)$.

\section{Discussion}

Several points emerge from the present study. 1) The ability of glucose to elevate cAMP levels in alloxan poisoned islets was reduced and was parallelled by an inhibition of insulin secretion. 2) Compounds (glucose and 3-0-methylglucose) which completely protect against alloxan poisoning of glucose-induced insulin release, maintained the ability of glucose to elevate cAMP levels while glyceraldehyde, which only marginally protected glucose-induced secretion, barely preserved the response of the cAMP system. 3) Protection by glucose did not appear to be related to its ability to elevate cAMP or promote insulin secretion since removal of extracellular calcium, which blocked both these responses $[14,21,22]$ did not alter its protective ability. 4) While alloxan significantly impaired the ability of islets to form ${ }^{3} \mathrm{H}_{2} \mathrm{O}$ from $\left[5-{ }^{3} \mathrm{H}\right]$ glucose, the effect was small in comparison to the complete blockade of insulin release.

That glucose elevates cAMP levels in isolated islets has been amply documented [12-16]. How this elevation is mediated, either directly through a glucose-receptor mechanism involving the intact glucose molecule or indirectly via a metabolite or cofactor of glucose metabolism is not fully understood. Recently however, Capito and Hedeskov [23] have demonstrated a direct effect of glucose on cAMP accumulation in mouse islet homogenates. This elevation was not blocked by mannoheptulose, a 7-carbon sugar which blocks glucose phosphorylation [24]. The exact interpretation of these results is not clear however, since it is known that mannoheptulose blocks glucose-stimulated cAMP accumulation in intact islet tissue $[14,25]$. Since alloxan caused a dose-dependent decrease in both stimulated secretion and cAMP levels it might be postulated that the pronounced inhibition of glucose-induced secretion after alloxan is the result of a rapid inactivation of the adenylate cyclase system. This inhibition of adenylate cyclase might occur by direct alteration of the enzyme itself or through changes in the cofactors necessary for enzyme activation. For example, it has recently been shown $[26,27]$ that alloxan alters the ionic properties of B-cell membranes and since extracellular calcium 
appears essential for glucose-induced accumulation of cAMP in islets $[14,22]$ such ionic changes may result in a decreased enzymatic response.

The mechanism(s) through which glucose or 3-0methylglucose protect against alloxan poisoning is not known. Perhaps the simplest explanation for hexose-protection is that various compounds might prevent the transport of alloxan into the cell $[28,29]$ and its ability to interact and alter the adenylate cyclase system. Glucose, mannose, and 3-0-methylglucose, compounds which presumably utilise the same transport system $[30,31]$ all protect against alloxan. However, it has recently been demonstrated that while 3-0-methylglucose prevents alloxan accumulation in islets, glucose and mannose actually increase the uptake of the compound [32].

It might also be suggested that these protective compounds interfere with the ability of alloxan to interact directly with the adenylate cyclase system. However, it should be noted that 3-0-methylglucose did not elevate cAMP levels or interfere with the ability of high glucose to do so. Therefore, while a direct protective effect of glucose on adenylate cyclase cannot be ruled out, a direct interaction of 3-0methylglucose with adenylate cyclase at least at the glucose-sensitive site appears unlikely. Other possibilities might include endogenously generated cAMP or hexose metabolites as protecting agents. However, these possibilities are apparently excluded because 3-0-methylglucose is not metabolised by islets and does not elevate cAMP, the protective effect of glucose occurs in the absence of elevated cAMP (by omitting extracellular $\mathrm{Ca}^{++}$), and glyceraldehyde increases cAMP in islet tissue [15] but does not significantly protect against alloxan. Of course, the possibility that these protecting compounds work by different mechanisms cannot be excluded.

From the present results, it does not appear that a primary blockage of total glucose utilisation can account for the pronounced reduction in glucosestimulated secretion. However, the results on total glucose usage must be interpreted with caution. The use of the $\left[5-{ }^{3} \mathrm{H}\right]$ glucose derivative appears to measure accurately total glucose flux via glycolysis and the pentose phosphate shunt [20] but yields no information on the ratio of glucose metabolised by each pathway. Alloxan might cause a preferential augmentation or reduction of either route of metabolism. In addition, usage rates yield no information on glucose oxidation rates. Recently, it has been shown that alloxan profoundly inhibits glucose oxidation in mouse islets and it was suggested that the mitochondria may be a primary target for alloxan action [33]. While it is possible that glucose or man- nose derived metabolites or cofactors might somehow spare the mitochondria from alloxan the mechanism of 3-0-methylglucose protection remains puzzling unless alternate mechanisms of protection are postulated.

Acknowledgements. The expert technical assistance of Mrs. Joy Brothers, Ms. Shirley Hill, Ms. Mette Bosch, Mrs. Sandra Smith, Mr. Duane Martin and Mrs. Betty Cordes is gratefully acknowledged. All the experiments reported in this paper were conducted in the Departments of Pharmacology and Pediatrics, Washington University School of Medicine, St. Louis, Mo and were supported by the United States Public Health Service Grants AM-10591 and AM-17810, the Diabetes and Endocrinology Center Grant AM17904, and a grant from the American Diabetes Association. Franz M. Matschinsky is an Established Investigator of the American Diabetes Association.

\section{References}

1. Dunn, J. S., Sheehan, H. L., McLetchie, N. G. B.: Necrosis of the islets of Langerhans produced experimentally. Lancet 1943 I, 484-487

2. Bhattacharya, G.: Protection against alloxan diabetes by mannose and fructose. Science 117, 230-231 (1953)

3. Tomita, T., Lacy, P. E., Matschinsky, F. M., McDaniel, M. L.: Effect of alloxan on insulin secretion in rat islets in vitro. Diabetes 23, 517-524 (1974)

4. McDaniel, M. L., Anderson, S., Fink, J., Roth, C., Lacy, P. E.: Effects of alloxan on permeability and hexose transport in rat pancreatic islets. Endocrinology 97, 68-75 (1975)

5. Tomita, T., Scarpelli, D. G.: Interaction of cyclic AMP on insulin secretion in isolated rat islets perifused in vitro. Endocrinology 100, 1327-1333 (1977)

6. Pagliara, A.S., Stillings, S.N., Zawalich, W.S., Williams, A. D., Matschinsky, F. M.: Glucose and 3-0-methylglucose protection against alloxan poisoning of pancreatic alpha and beta cells. Diabetes 26, 973-979 (1977)

7. Schenyius, A., Täljedal, I-B.: On the mechanism of glucose protection against alloxan toxicity. Diabetologia 7, 252-255 (1971)

8. Zawalich, W. S., Beidler, L. M.: Glucose and alloxan interactions in the pancreatic islets. Am. J. Physiol. 224, 963-966 (1973)

9. Rossini, A. B., Berger, M., Shadden, J., Cahill, G. F., Jr.: Beta cell protection to alloxan necrosis by anomers of $D$-glucose. Science 183, 424 (1974)

10. McDaniel, M. L., Roth, C. E., Fink, C. J., Lacy, P. E.: Effect of anomers of D-glucose on alloxan inhibition of insulin release in isolated perifused pancreatic islets. Endocrinology 99, 535-540 (1976)

11. Niki, A., Niki, H., Miwa, I., Lin, B. J.: Interaction of alloxan and anomers of D-glucose on glucose-induced insulin secretion and biosynthesis in vitro. Diabetes 25, 574-579 (1976)

12. Charles, M. A., Fanska, R., Schmid, F. G., Forsham, P. H., Grodsky, G. M.: Adenosine $3^{\prime}$, 5'-monophosphate in pancreatic islets: glucose-induced insulin release. Science $\mathbf{1 7 9}$, 569-571 (1973)

13. Grill, V., Cerasi, E.: Stimulation by D-glucose of cyclic adenosine $3^{\prime}, 5^{\prime}$-monophosphate accumulation and insulin release in isolated pancreatic islets of the rat. J. Biol. Chem. 249, 4196-4201 (1974)

14. Zawalich, W. S., Karl, R.C., Ferrendelli, J. A., Matschinsky, F. M.: Factors governing glucose induced elevation of cyclic $3^{\prime}$, 
5' AMP levels in pancreatic islets. Diabetologia 11, 231-235 (1975)

15. Hellman, B., Idahl, L.-Å., Lernmark, A., Täljedal, I.-B.: The pancreatic B-cell recognition of insulin secretagogues: does cyclic AMP mediate the effect of glucose? Proc. Natl. Acad. Sci. USA 71, 3405-3409 (1974)

16. Schauder, P., Arends, J., Schindler, B., Ebert, R., Frerichs, H.: Permissive effect of glucose on the glucagon-induced accumulation of cAMP in isolated rat pancreatic islets. Diabetologia 13, 171-175 (1977)

17. Morgan, C. R., Lazarow, A.: Immunoassay of insulin: two antibody system. Diabetes 12, 115-126 (1963)

18. Zawalich, W.S., Matschinsky, F. M.: Sequential analysis of the releasing and fuel function of glucose in isolated perifused islets. Endocrinology 100, 1-8 (1977)

19. Zawalich, W. S., Pagliara, A. S., Matschinsky, F. M.: Effects of iodoacetate, mannoheptulose and 3-0-methylglucose on the secretory function and metabolism of isolated pancreatic islets. Endocrinology 100, 1276-1283 (1977)

20. Ashcroft, S. J.H., Weerasinghe, L.C.C., Bassett, J. M., Randle, P. J.: The pentose cycle and insulin release in mouse pancreatic islets. Biochem. J. 126, 525-532 (1972)

21. Curry, D. L., Bennett, L. L., Grodsky, G. M.: Requirement for calcium ion in insulin secretion by the perfused rat pancreas. Am. J. Physiol. 214, 172-174 (1968)

22. Charles, M. A., Lawecki, J., Pictet, R., Grodsky, G. M.: Insulin secretion: interrelationships of glucose, cyclic adenosine $3^{\prime}: 5^{\prime}$-monophosphate and calcium. J. Biol. Chem. 250, 6134-6140 (1975)

23. Capito, K., Hedeskov, C. J.: Effects of glucose, glucose metabolites and calcium ions on adenylate cyclase activity in homogenates of mouse pancreatic islets. Biochem. J. 162, 569-573 (1977)

24. Coore, H. G., Randle, P. J.: Inhibition of glucose phosphorylation by mannoheptulose. Biochem. J. 91, 56-59 (1964)
25. Capito, K., Hedeskov, C. J.: The effect of starvation on phosphodiesterase activity and the content of adenosine $3^{\prime}: 5^{\prime}-$ monophosphate in isolated mouse pancreatic islets. Biochem. J. 142, 653-658 (1974)

26. Idahl, L-Å., Lernmark, A., Sehlin, J., Täljedal, I-B.: Alloxan cytotoxicity in vitro: Inhibition of rubidium ion pumping in pancreatic $\beta$-cells. Biochem. J. 162, 9-18 (1977)

27. Capito, K., Formby, B.: Alloxan activation of calcium ion pump in mouse pancreatic islets. Diabetologia 13, 386 (1977)

28. Hammarström, L., Ullberg, S.: Specific uptake of ${ }^{14} \mathrm{C}$-alloxan in the pancreatic islets. Nature 212, 708-709 (1966)

29. Hammarström, L., Hellman, B., Ullberg, S.: On the accumulation of alloxan in the pancreatic $\beta$-cells. Diabetologia 2, 340-345 (1966)

30. Hellman, B., Sehlin, J., Täljedal, I-B.: Evidence for mediated transport of glucose in mammalian pancreatic $\beta$-cells. Biochim. Biophys. Acta 241, 147-154 (1971)

31. Park, C. R., Crofford, O. B., Kono, T.: Mediated (nonactive) transport of glucose in mammalian cells and its regulation. J. Gen. Physiol. 52, 296-313 (1968)

32. Weaver, D. C., McDaniel, M. L., Lacy, P. E.: Alloxan uptake by isolated rat islets. Endocrinology 102, 1847-1855 (1978)

33. Borg, L. A. H., Eide, S., Andersson, A., Agren A., Ostenson, C. G., Hellerström, C.: In vitro effects of alloxan on glucose utilization and ATP content of isolated mouse pancreatic islets. Diabetologia 13, 383-384 (1977)

Received: March 28, 1978,

and in revised form: September 4, 1978

Walter S. Zawalich

Department of Physiology G 4

University of Pennsylvania

School of Medicine

Philadelphia, PA 19104

USA 